\title{
INTEREST RATE REGIME AND THE PERFORMANCE OF THE NIGERIAN CAPITAL MARKET
}

\author{
Jeroh Edirin \\ Delta State University, Abraka, Nigeria \\ jeroh4laff@yahoo.com \\ C. M. Ekwueme \\ Nnamdi Azikiwe University, Awka,Anambra State, Nigeria \\ cm.ekwueme@unizik.edu.ng \\ ekwuemecm@gmail.com
}

\begin{abstract}
This study x-ray's the interest rates regime in Nigeria as it affects the performance of the Nigerian Capital Market. In order to achieve this objective, relevant data for a period of 33 years spanning from 1981 - 2013 were obtained from the Factbook of the Nigerian Stock Exchange, CBN Statistical Bulletin as well as the annual accounts of quoted firms for the relevant years. The data obtained were analysed with the Ordinary Least Square (OLS) technique. The result from our analysis reveal among others that changes in interest rate regimes have majorly influenced the level of the performance of the Nigerian Capital Market. Based on the above, we recommend that capital market regulators and other regulatory agencies should keep an eye on movements in interest rates and the Minimum Rediscount Rate (MRR) (now MPR) and watch their trend. We also recommend that efforts must be put in place to establish a policy review and reassessment mechanism that would help in assessing the impact of selected policy measures on the economy so that policy makers would know the effectiveness and efficiency of designed policies and be guided in the policy review and development process in the country.
\end{abstract}

\section{Keywords}

Lending Rate; SAP; Capital Market; Equity Rate; MRR; Financial Sector Reforms; Nigeria

\section{JEL Classification}

E4; E44; N2

\section{Introduction}

The Federal Government of Nigeria in 1986, introduced a comprehensive economic restructuring programme (The Structural Adjustment Programme [SAP]) which emphasized the need for increased reliance on market forces. In order to pursue the objectives of introducing the SAP, Financial Sector reforms were initiated by the Federal Government. The reforms, which focused on interest rate administration, structural changes, reduction of credit control, free entry into the banking sector, liberalization of capital flows, etc (Obamuyi \& Olorunfemi, 2011), encompasses both financial market liberalization and institutional building in the financial sector. The broad objectives of financial sector reform amongst others included:

i. Improving efficiency by increasing the level of savings through the removal of controls on rate of interest.

ii. Elimination of non-price rationing of credit to reduce misdirected credit and increase competition.

iii. Enhancing of institutional structure and supervision. 
Between 1970 - 1986 a period described as the pre-reform period (Obamuyi \& Olorunfemi, 2011), the monetary policy environment in Nigeria was highly regulated (Ogede, 2013). In fact it has been argued in the literature (Soyibo \& Olayiwola, 2000; Obamuyi \& Olorunfemi, 2011; Ojima \& Emerenini, 2015) that during the pre-reform period, policies of directed credits as well as that of interest rate ceiling and restrictive monetary expansion were the rule rather than the exception. This according to Obamuyi \& Olorunfemi (2011) resulted to a situation where interest rates policy instruments became fixed with marginal increases. By August 1987, the Central Bank of Nigeria (CBN) liberalized the interest rate regime (Ikhide \& Alawode, 2001) and adopted the policy of fixing only its Minimum Rediscount Rate (MRR). This policy as noted by scholars (Obamuyi, 2009; Obamuyi \& Olorunfemi, 2011; Udoka \& Anyingang, 2012; Ogede, 2013) was actually put in place to achieve efficiency in the financial sector, thus engendering financial deepening.

It is noteworthy however that the Minimum Rediscount Rate (MRR) according to CBN (2006) is the official interest rate of the CBN, which is the major determinant of prevailing interest rates in the economy. Thus, decisions taken by the CBN on the MRR definitely affect the level of economic activities as well as the prices of goods and services in the country. This policy was however modified in 1989, when according to Siyanbola, Sobande \& Adedeji (2012) and Onwumere, Okore \& Ibe (2012), the CBN issued further directives on the required spreads between deposit and lending rates in the country. In addition to the above development, one should note that by 1991, a maximum margin was prescribed between the average cost of capital of each bank and its maximum lending rates in the country; but by 1992, financial institutions were however required to maintain only a specified spread which was between their average cost of capital and their maximum lending rates (CBN, 2006; Imoisi et al, 2010; Siyanbola et.al., 2012; Ogunbiyi \& Ihejirika, 2014). With this, partial deregulation was however, restored.

Furthermore, CBN (2006) maintained that by 1993, the maximum lending rate ceiling was removed. This, according to Akingunola et al (2012), made interest rates in the country to increase to an unprecedented level, vis $a$ vis the trend of inflation rates that was prevailing in the country as at then. Thus interest rates in 1993 were volatile and rose to unprecedented levels, thereby exerting negative impact on investments in the productive sectors of the economy, while volatile inter-bank rates undermined the efficacy of open market operations and general stability in the financial system. On the basis of the foregoing developments, some measures of regulation were introduced in the management of interest rates, resulting to what Udoka \& Anyingang (2012) described as policy reversal in 1994. This time, there was the claim that a wide variation and unnecessarily high rate of interest exist under the complete deregulation of interest rate (Udoka \& Anyingang, 2012). Thus, deposit rates were set at 12 per cent per annum, while a ceiling of 21 per cent per annum was fixed for lending. This measure of regulating interest rate as noted by Udoka \& Anyingang (2012) was however retained in 1995, though with little modification for flexibility.

By October, 1996 total deregulation of interest rates was again adopted due to the fact that the controls introduced in 1994 and 1995 had negative economic effects (Imoisi, Uzomba \& Olatunji, 2010; Siyanbola, Sobande \& Adedeji, 2012; Akingunola et al, 2012). As a result of the total deregulation of interest rates in 1996, Udoka \& Anyingang (2012) opine that banks were given freedom to determine the structure of interest rates in consultation with their customers. The CBN, however, retained the discretionary power to intervene in the money market to ensure orderly developments in interest rates (Akingunola et al, 2012; Udoka \& Anyingang, 2012). The 
deregulation of interest rates brought in liquidity glut, high interest rates and volatile inter-bank interest rates which became a permanent feature in the Nigerian economy. However, the deregulation policy on interest rate was retained in 1997 (Akingunola et al, 2012) though by October 22, 2002 as noted by Ayodele, Obafemi \& Akongwale (2013), the CBN reached a tripartite agreement on interest rate moderation with the banks operating in the country. In that agreement, a decision was reached to lower interest rate to a point where lending rates would not exceed $4 \%$ above the MRR. That notwithstanding, we must note however that lending rate between $1997-2006$ according to Ogede (2013), did not show a significant trend in reduction with an average of $22 \%$, despite the declining deposit rate that was averaging $15 \%$. By December 8, 2006, a policy referred to as the Monetary Policy Rate (MPR) replaced the Minimum Rediscount Rate (MRR) as a cornerstone of monetary policy implementation (Ayodele et al., 2013; Doguwa \& Essien, 2013). The MPR as noted by (Akingunola et al, 2012) was introduced as an instrument targeted at correcting the excessive short-term interest rate volatility; especially with the setting of the Seven (7) to 13 (thirteen) percents corridor. They further pointed that this measure allowed the Central Bank of Nigeria (CBN) to actively intervene in the money market to achieve the interest rate target.

In September 2013, the CBN Monetary Policy Committee (MPC) met with a view to assessing the challenges facing the Nigerian economy, as well as reviewing economic developments in the country (CBN, 2013). The fallout of the meeting was the fixing of the benchmark rate (MPR) at 12 percent with an asymmetric corridor of +/- 200bps. Cash Reserve Ratio (CRR) on private sector deposits stood at 12 percent, while that of public sector deposit was 50 percent. Liquidity ratio was fixed at 30 percent of total assets, while Net open position of 1.0 percent of shareholders' funds was maintained (CBN, 2013). CBN (2013) maintained that interest rate in Nigeria averaged 9.55 Percent from 2007 until 2013, reaching an all time high of 12 Percent in October, 2011 and a record low of 6 Percent in July of 2009. It may be disheartening to know that this resulting low interest rate according to Obamuyi \& Olorunfemi (2011), discouraged saving mobilization and the channeling of the mobilized savings through the system. This trend as they noted, may have a negative impact on stock market activities as well as economic growth.

On the basis of the aforementioned, this study is designed to see how the policies on interest rates over the years have affected selected performance indices in the Nigerian Stock Market by looking at the period 1981-2013.

\section{Theoretical Framework and Review of Related Literature}

\subsection{Theoretical Framework}

Notable theories on finance and development (McKinnon, 1973 and Shaw, 1973) criticized the dominant neo-classical monetary theories and the Keynesian counter arguments (Odili \& Ede, 2015). Odili \& Ede (2015) further opine that the neoclassical monetary growth models postulate that high-positive interest rate have a direct impact on savings and investment. Within this school of thought, Odili \& Ede (2015) were of the view that money is regarded as a substitute for physical assets and productive investments. Keynesian economists on the other hand, argue that lowinterest rate increases investment, income and eventually savings. McKinnon (1973) and Shaw (1973) advanced arguments in favour of a complementary relationship between financial and physical assets as opposed to the substitutability theory by the neoclassical theory of interest rate. 
On a general note, the barometers for measuring the performance of the economy include among others real GDP growth rate, interest rate, rate of inflation, the exchange rate, fiscal position and the debt position. Of these, interest rates is believed to have a strong effect on stock market activity as they impinge directly on the state of corporate activity in any country. This is because interest rate is the financial prices for credit thereby affecting the allocation of resources, prices as well as profitability. Ultimately, fluctuations in interest rates are believed to be reflected in the prices of shares - an indicator of market performance. For instance, lowering of interest rate on demand and savings deposits will improve returns to investment holding factors such as risk, transaction costs, etc. constant. This of course, has a multiplier effect on the demand and share price of affected listed equities.

On the basis of the above, this study is hinged on the assumptions of the McKinnonShaw theory (1973).

\subsection{Factors Affecting Interest Rates in Nigeria}

The behavior of interest rates in Nigeria over the years can be traceable to a number of factors. In the views of Akingunola et al (2012) and Udoka \& Anyingang (2012), such factors include, but not limited to:

i. The high rate of domestic inflation arising from the huge fiscal deficit of Federal Government which was financed mainly by Central Bank;

ii. The undue discretion which the deregulation of interest rates conferred on key market players in pricing their funds as well as the arbitraging activities of market speculators;

iii. Technical insolvency and serious cash flow problems on the part of some weak banks resulting in distress borrowing;

iv. The investment demand: The higher the level of investment demand, the higher the level of interest rates. Similarly, the lower the level of investment demand, the lower the level of interest rates;

v. The use of stabilization securities and the system of allocation of foreign exchange both of which induced the sterilization of large funds at the CBN; and

vi. The demand for money or liquidity preference in addition to the quantity of money or money supply in the economy

vii. The level of savings (or conversely, the level of consumption).

\subsection{Overview and Evolution of the Nigerian Capital Market}

Capital markets consists of financial institutions that are harnessed together for the purpose of fund mobilization for use by both the public and private sectors of an economy. Akingbohungbe (1996) defined the capital market as the market where both long-term and medium-term finance is raised. It is what Ekezie (2002) described as a market for dealings (i.e. lending and borrowing) in longer-term loanable funds. In the views of Atoyebi, Ishola, Kadiri, Adekunjo \& Ogundeji (2013), a capital market is a network of specialized financial institutions, series of mechanism, process and infrastructure that are engaged in the facilitation of the needed contacts between the suppliers of fund and the ultimate users of such funds for investment or other purposes in the economy. This clearly shows that capital markets are markets for trading long term financial securities which includes ordinary shares, long term debt securities such as debentures, unsecured loan stock and convertible bonds. Owolabi \& Adegbite (2014) also added that other public sector securities like gilt-edged stocks, treasury bills and government bonds are traded on the floor of capital markets.

Several studies have drawn a link between capital markets and the socio-economic growth and development of most economies (Shaw, 1973; Levine \& Zervos, 1996; 
Osaze, 2000; Donwa \& Odia, 2010; Ogege \& Ezike, 2012; Atoyebi et al, 2013). This is because efficient financial intermediation is very crucial to economic development (Mishra, Mishra, Mishra, \& Mishra, 2010) thereby influencing growth positively. In the views of Osaze (2000), an efficient capital market is essential for long term growth in capital formation. By implication, it becomes obvious that capital markets helps in the mobilization and efficient allocation of capital for investment purposes. The capital market is made up of the primary and secondary markets (Inaya \& Proso, 2013). While the primary market is concerned with the raising of new capital (new issues) the secondary market on the other hand is the market for the sale and purchase of existing securities. Before 1959, almost all formal savings and deposits in Nigeria as noted by SEC (2009), were in the banking system. According to Donwa \& Odia (2011), the period from 1960 - 1986 was marked with the enactment of various Acts as well as the emergence of the securities markets and instruments in addition to the development of several policies relating to financial and non financial sector.

Accordingly, resulting from some of the Acts enacted, capital market in Nigeria started far back in 1961 following the establishment of the Lagos Stock Exchange on September 15, 1960 which began trading on June, 5, 1961 (SEC, 2009; Donwa \& Odia, 2011; Ogege \& Ezike, 2012). The Lagos Stock Exchange as Donwa \& Odia (2011) pointed, was actually established as a result of the recommendation of the Barback Committee of 1957. On inception, the Lagos Stock Exchange was a self regulatory institution which was incorporated under the company's ordinance as an association limited by guarantee (Ogege \& Ezike, 2012), with about 19 listed securities as at June, 1961. By 1977, there was a reorganization of the Stock Exchange by the Indigenization Decree of 1977 which changed the name from the Lagos Stock Exchange to The Nigerian Stock Exchange following recommendations of the Industrial Enterprise Panel (Adeosun Panel) of 1975 (Donwa \& Odia, 2011) and the Financial System Review Committee (Pius Okigbo Committee) of 1976 (SEC, 2009; Donwa \& Odia, 2011; Ogege \& Ezike, 2012; Atoyebi et al, 2013). Between 1977 and 1980, additional trading floors were opened in Port-Harcourt and Kaduna. As at 2008, NSE has opened trading floors in Kano, Yola, Calabar, Illorin, Uyo and Abeokuta.

Before then, there was the establishment of the Capital Issues Committee (CIC) by the Central Bank of Nigeria (CBN) sometime in 1962. Resulting from an increase on the level of economic activities in the capital market the Capital Issues Commission (CIC) was established in March 1973, to take over the activities of the Capital Issues Committee since the need to provide a stronger institutional support to the securities issuance process as well as the regulation of the pricing and timing of securities that would be offered to the public could not be overemphasized. It must be noted however, that SEC (2009) maintained that neither the Committee nor the Commission was conceived as the apex regulatory agency for the capital market as at that time. Between 1978 - 1979, efforts were made to replace the Capital Issues Commission with the Securities and Exchange Commission (SEC) Act 1979 (re-enacted as Decree No.29 1988) (SEC, 2009) which made SEC the apex monitoring institution of the Nigerian Capital Market (SEC, 2009; Donwa \& Odia, 2011; Ogege \& Ezike, 2012; Atoyebi et al, 2013). While the Nigerian Stock Exchange (NSE) remains the central point of the Nigerian Capital Market, the regulation of the activities in the Nigerian capital market rests on the hands of the Securities and Exchange Commission (SEC), though it is supervised by the Federal Ministry of Finance.

In 1996, a 7-man panel headed by one Chief Dennis Odife as noted by SEC (2009), conducted a review of the capital market and SEC's role and effectiveness and gave recommendations which led to the enactment of the Investment and Securities Act No.45 of 1999 (ISA). The Act was promulgated in May 26, 1999 (SEC, 2009) and 
repealed the SEC Act of 1988. Accordingly, by 2007, the ISA 1999 was re-enacted. Below is Figure that clearly summarizes the evolution of the capital market in Nigeria.

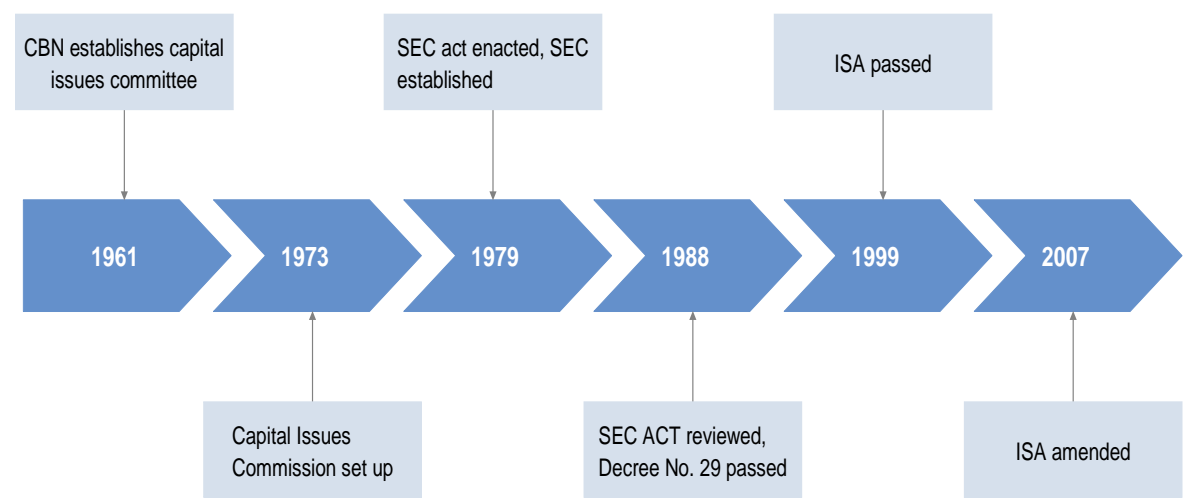

Figure 1 Evolution of The Nigerian Capital Market

Source: SEC (2009)

\section{Methodology}

This research work was done by the use of the quasi experimental Design. Data on companies quoted on the floor of the Nigerian Stock Exchange for the period 1981 2013 was used in this study, and the Ordinary Least Square regression analysis was specifically adopted to see how changes in interest rate regime had influenced the performance of the Nigerian Capital Market. This technique is desirable because it is a consistent and unbiased estimator. The linear relationship between the dependent variable and the independent variable is determined.

\subsection{Model Specification}

For the purpose of this study, the following model was developed in its log form and adopted as follows:

LMPERF $=b 0+b 1$ LIR $+b 2 L M R R+\mathrm{Ut}$

$$
\mathrm{b}_{1}<0
$$

Where: MPERF= Stock Market Performance (proxied by Stock Market Capitalization)

$$
\begin{array}{ll}
\text { IR } & =\text { Interest rate } \\
\text { MRR } & =\text { Minimum Rediscount Rate } \\
\mathrm{U}_{\mathrm{t}} & =\text { Random Variable } \\
\mathrm{L} & =\text { Natural Logarithm } \\
\mathrm{b}_{0} & =\text { Constant } \\
\mathrm{b}_{1}, \mathrm{~b}_{2} & =\text { Parameter }
\end{array}
$$

Decision Rule: Where the calculated f-ratio is greater than the table value, we reject the null hypothesis and accept the alternative hypothesis. Similarly, where the calculated f-ratio is less than the table value, we accept the null hypothesis and reject the alternative hypothesis. 


\section{Results and Discussion}

In this section, we start by presenting the trend of interest rate movement following the changes in interest rate regime over the years. We also analyzed the trend of market capitalization for the period under study. In Figure 2, we present the trend of interest rate movement while Figure 3 shows the movement of the components of market capitalization for the period under study (1981 - 2013).

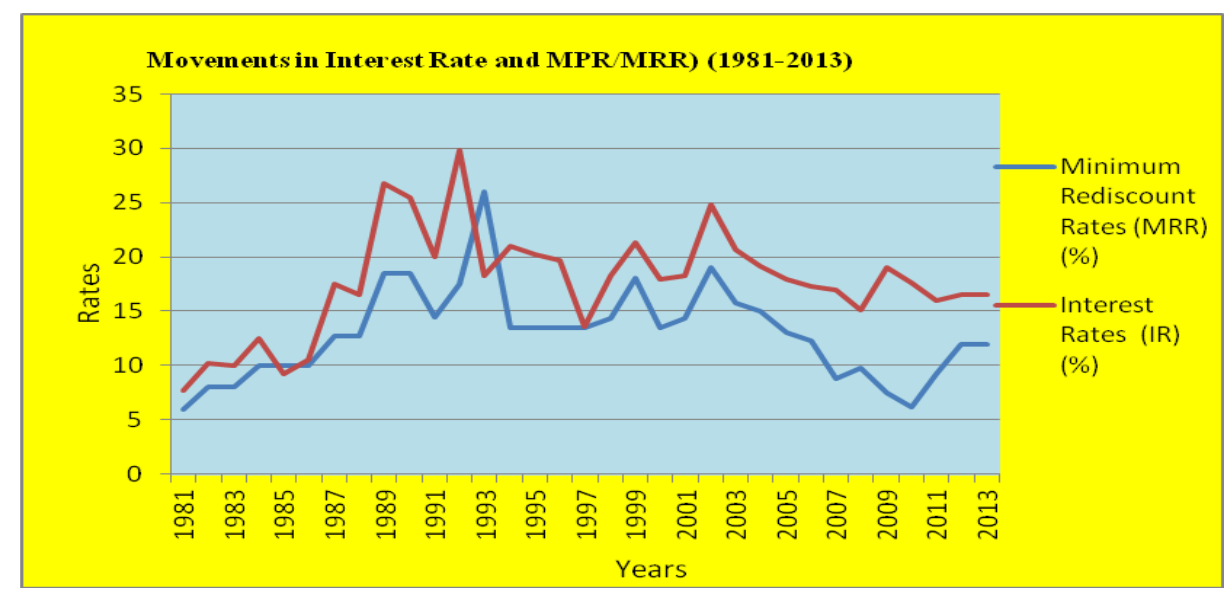

Figure 2 Trend of Interest Rate and MPR/MRR in Nigeria (1981-2013)

From Fig. 2, it is obvious that interest rates for the various years were mostly higher than the Minimum Rediscount Rate (MRR) except for 1985 (pre-reform period) and 1993. The reason for the trend of interest rate exhibited in 1993 could be traceable to the removal of the maximum lending rate ceiling in 1993 by the Central Bank of Nigeria (CBN) which saw interest rates rising to unprecedented levels. On the basis of this development, measures of regulation were introduced in the management of interest rates, resulting to what Udoka \& Anyingang (2012) described as policy reversal in 1994. Notice also that after the policy reversal in 1994, interest rates were placed on points above the MRR, now replaced by MPR.

We also analyzed the trend of market capitalization for the period and observed that market capitalization had exhibited an upward movement all through the period, except for the sharp downward trend indicated between 2008. This downward movement could be attributed to the impact of the global financial crisis on activities of the stock market (Jeroh, 2013). However, beginning from 2009 and 2010, we observe also that market capitalization is exhibiting upward movement. This upward movement after 2009 could be as a result of policy measures taken by the regulatory bodies in Nigeria. 


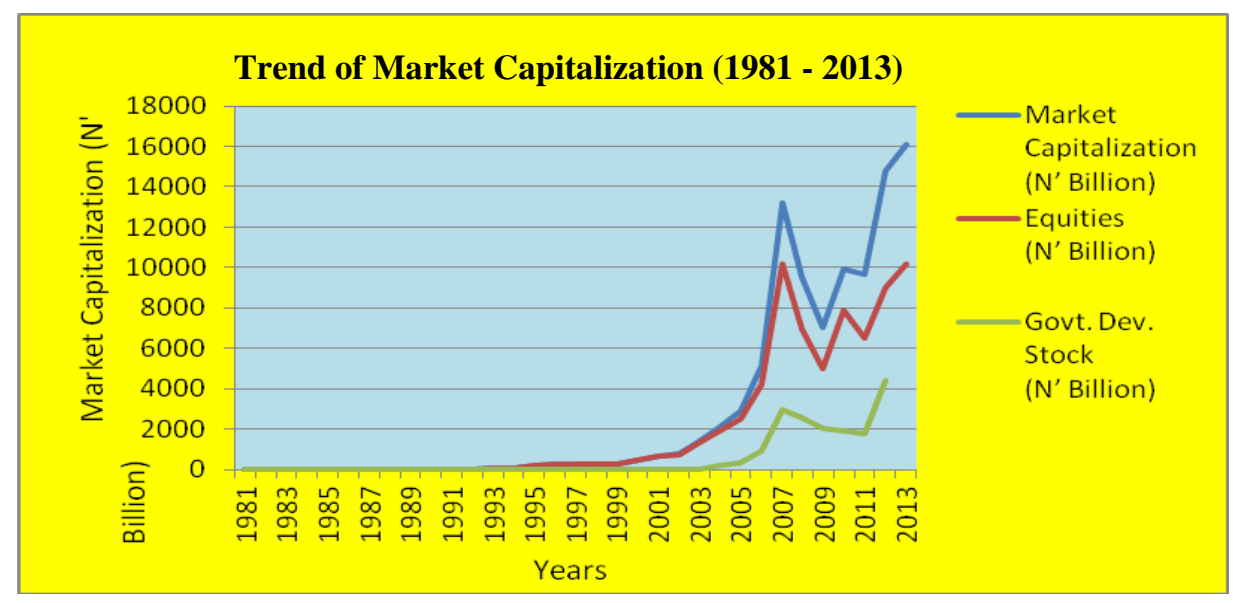

Figure 3 Movement of Componenents of Market Capitalization in Nigeria

(1981-2013)

\subsection{Correlation Analysis}

This section presents the correlation results obtained from the SPSS output. The primary objective of this analysis is to measure the strength or degree of linear association between the variables of interest rates, minimum rediscount rates and market capitalization. This was done through the Pearson Correlation Coefficient (PCC), Variance Inflator Factor (VIF) and Tolerance Level (TL). Nachmias \& Nachmias (2009) opined that there could be strong positive relationship, a weak positive relationship and no relationship. Thus, Pearson's $r$ ranges from -1.0 to 1.0, where a negative coefficient indicates inverse relations between the variables. The VIF and TL were used to establish whether there is multi co-linearity between the variables of the study. Hence, when VIF and TL are closer to 1, it indicates the existence of multi co-linearity between the variables.

Table 1 Correlation for LMCAP, LIR and MRR

\begin{tabular}{c|c|c|c|c|c}
\hline \multicolumn{4}{|c|}{ Pearson Correlation } & \multirow{2}{\text{Variance}}{$\begin{array}{c}\text { Inflator } \\
\text { Factor (VIF) }\end{array}$} & $\begin{array}{c}\text { Tolerance } \\
\text { Level (TL) }\end{array}$ \\
\cline { 1 - 4 } Variable & Zero & Partial & Part & 1.000 & 1.000 \\
\hline LIRR & -.079 & .246 & .229 & 1.000 & 1.000 \\
\hline LMRR & -.368 & -.427 & -.426 & Source: SPSS Output
\end{tabular}

Table 1 indicates a perfect co-linearity between market capitalization, interest rates and minimum rediscount rates. This was supported by the results obtained from the VIF value (1.000) and TL value (1.000). With the Pearson Correlation using Zero, Partial and Part Correlation, the degree of association is negative and weak. However, using the zero correlation alone, the degree of association for interest rates is negative and strong but it is not sufficient to say that the degree of association when using the aggregates of zero, partial and part correlations. 


\subsection{Regression Analysis}

This section involved the presentation and analysis of the regression results as well as the test of the research hypotheses.

Table 2 Regression Result for the Variables

\begin{tabular}{|c|c|c|c|}
\hline Variables & Coefficients & t-statistic & Prob. \\
\hline Constant $_{\text {(Model) }}$ & 6054.517 & 2.002 & .054 \\
\hline $\begin{array}{l}\mathrm{LIRR}_{1} \\
\mathrm{MRR}_{1}\end{array}$ & $\begin{array}{c}303.444 \\
-659.054\end{array}$ & $\begin{array}{c}1.393 \\
-2.588\end{array}$ & $\begin{array}{l}.174 \\
.015\end{array}$ \\
\hline
\end{tabular}

As shown in Table 2, the model for this study designed to capture the relationship of movements in interest rate and the minimum rediscount rates with the level of he performance of the Nigerian capital market (p-value $=.054)$ was statistically significant at 5 percent or lower.

Table 3 Goodness of fit through R Square (Model)

\begin{tabular}{|c|c|c|c|c|}
\hline Model $_{1}$ & $\mathbf{R}$ & $\begin{array}{c}\mathbf{R} \\
\text { Square }\end{array}$ & $\begin{array}{l}\text { Adjusted R } \\
\text { Square } \\
\end{array}$ & $\begin{array}{l}\text { Std. Error of the } \\
\text { Estimate }\end{array}$ \\
\hline 1 & $0.933^{a}$ & 0.877 & 0.834 & 4516.61245 \\
\hline
\end{tabular}

As shown in Table 3, both $\mathrm{R}^{2}$ and adjusted $\mathrm{R}^{2}$ measure the fitness of the model i.e. they measure the proportion of the variation in dependent variable explained by the model. But since adjusted $\mathrm{R}^{2}$ is the modification for the limitation of $\mathrm{R}^{2}$ the value of the adjusted $\mathrm{R}^{2}$ is considered to measure the fitness of the model. Thus, as it is shown above, the value of adjusted $\mathrm{R}^{2}$ is 0.834 , suggesting that interest rates and minimum rediscount rates in the model is explaining $83 \%$ variation on market capitalization. Thus, we can understand that the model of the study is providing a good fit to the data since the unexplained variation is just $17 \%$.

\subsection{Test of Hypothesis}

The test of hypothesis was based on the f-ratio. The results was obtained from the Analysis of Variance (ANOVA). The hypotheses for the study to be tested is hereby stated below:

$\mathrm{H}_{01}$ : $\quad$ There is no significant relationship between changes in interest rate regime and the performance of the Nigeria Capital Market.

$\mathrm{H}_{\mathrm{A} 1}$ : $\quad$ There is a significant relationship between changes in interest rate regime and the performance of the Nigerian Capital Market.

Table 4 ANOVA Result

\begin{tabular}{|ll|c|c|c|c|c|}
\hline \multicolumn{1}{|c|}{ Model $_{1}$} & Sum of Squares & Df & Mean Square & f-ratio & Sig. \\
\hline 1 & Regression & 141388494.249 & 2 & 70694247.125 & 33.465 & $.044^{\mathrm{b}}$ \\
& Residual & 611993640.886 & 30 & 20399788.030 & & \\
\hline
\end{tabular}




\section{Total} 753382135.135

\section{2}

Source: SPSS Output

a. Predictors: (Constant), LIR, LMRR

b. Dependent Variable: LMCAP

From Table 4, it can be observed that the independent variable give a significant effect on the dependent variable, where f-ratio is 33.465 with a p-value of less than 0.05 (i.e. $\mathrm{p}<0.44$ ) indicating that, overall, the model used for the study is significantly good enough in explaining the variation on the dependent variable.

Decision: Based on the f-ratio as shown in Table 4, we reject the null hypothesis which states that there is no significant relationship between changes in interest rate regime and the performance of the Nigerian Capital Market. Our conclusion is that there is a significant relationship between changes in interest rate regime and the performance of the Nigerian Capital Market.

\section{Conclusion}

This study was designed to look at changes in interest rates regimes in Nigeria in order to establish its impact on the performance of the Nigerian Capital Market for the period 1981 - 2013. It was observed that following the introduction of interest rate reform in Nigeria, interest rates for the various years were higher than the Minimum Rediscount Rate (MRR) now replaced by MPR except for 1993. The reason for the trend of interest rate exhibited in 1993 could be traceable to the removal of the maximum lending rate ceiling in 1993 by the Central Bank of Nigeria (CBN) which saw interest rates rising to unprecedented levels in line with rising inflation rates which rendered banks' high lending rates to become negative in real terms. This is as expected in the literature (Akingunola et al, 2012). On the basis of the this development, measures of regulation were introduced by government in order to manage interest rates, resulting to what Udoka \& Anyingang (2012) described as policy reversal in 1994.

From the analysis and test of the hypothesis, it was observed that changes in interest rate regimes have majorly influenced the level of the performance of the Nigerian Capital Market (proxied by market capitalization) during the period under study compared to the minimum rediscount rates, although minimum rediscount rates to some extent was found to have influenced the performance of the Nigerian Capital Market, but not as in the case of interest rates. Thus, the performance of the Nigerian Capital Market (proxied by market capitalization) is said to follow a random walk. In addition, there was a perfect co-linearity between market capitalization, interest rates and minimum rediscount rates.

From the aforementioned, we therefore conclude that there is a significant relationship between changes in interest rate regime and the performance of the Nigerian Capital Market.

\section{Recommendations}

Based on the outcome of our analysis and test of hypothesis, we recommend that capital market regulators and other regulatory agencies should keep an eye on movements in interest rates and the MRR (now MPR) and watch their trend. In light of the above, efforts must be put in place to establish a policy review and reassessment mechanism that would help in assessing the impact of selected policy measures on the economy. At least, this would enable policy makers to know the effectiveness and 
efficiency of designed policies which will to a large extent, guide in the policy review and development process in the country.

\section{References}

Akingbohungbe, S. S. (1996), The Role of the Financial System in the Development of the Nigerian Economy, Paper Presented at a Workshop Organized by Centre for Africa Law and Development Studies.

Akingunola, R. O., Adekanle, O. A., Ojodu, H. (2012), Impact of Interest Rate On capital Market Growth (A Case Of Nigeria), Universal Journal of Management and Social Sciences, 2(11), 1-24.

Atoyebi, K. O., Ishola, S. A., Kadiri, K. I., Adekunjo, F. O., Ogundeji, M. O. (2013), Capital Market and Economic Growth In Nigeria: An Empirical Analysis, Journal Of Humanities And Social Science, 6(6), 60-68.

Ayodele, O. S., Obafemi, F. N., Akongwale, S. (2013), Policy Option For Low and Sustainable Lending Rates In Nigeria, Mediterranean Journal of Social Sciences, 4(3), 147-158.

Central Bank of Nigeria (2006), How Does the Monetary Policy Decisions of the Central Bank of Nigeria Affect You? Part Two, Monetary Policy Series CBN/MPD/Series/03, Abuja: CBN Monetary Policy Department.

Central Bank of Nigeria (2013), Quarterly Economic Report Abuja: CBN.

Doguwa, S. I., Essien, S. N. (2013), The Role Of Central Bank of Nigeria's Analytical Balance Sheet and Monetary Survey In Monetary Policy Implementation, CBN Journal of Applied Statistics, 4(1), 119-138.

Donwa, P., Odia, J. (2010), An Empirical Analysis of the Impact of the Nigerian Capital Market on Her Socio-Economic Development, Journal Of Social Science, 24(2), 135-142.

Donwa, P., Odia, J. (2011), Effects Of Consolidation of the Banking Industry on the Nigerian Capital Market, Journal Of Economics, 2(1), 57-65.

Ekezie, E. S. (2002), The Elements of Banking: Money, Financial Institutes and Markets, Onitsha: Africana - Feb Publishers Limited.

Ikhide, S. I., Alawode, A. A. (2001), Financial Sector Reforms, Microeconomic Instability and The Order of Economic Liberation: The Evidence From Nigeria, Africa Economic Research Consortium Paper, 112, 944-953.

Imoisi, A. I., Uzomba, P. C., Olatunji, L. M. (2010), An Analysis of Interest and Exchange Rates Effect On the Nigerian Economy, 1975-2008, Asian Economic and Financial Review, 2(6), 648-657.

Inaya, L., Proso T. (2013), Introduction To Financial Management and Investment Analysis, Benin-City: Mareh Publishers Ltd.

Jeroh, E. (2013), The Global Financial Crisis and The Performance of Capital Markets of Developing Economies: Lessons From Nigeria, Acta Universitatis Danubius OECONOMICA, 9(3), 70-83.

Levine, R., Zervos, S. (1996), Stock Market Development and Long Run Growth, The World Bank Economic Review, 10(3), 323-339.

McKinnon, R. I. (1973), Money and Capital in Economic Development, Washington DC, USA: Brookings Institution, 1st ed.

Mishra, P. K., Mishra,U. S., Mishra, B. R., Mishra, P. (2010), Capital Market Efficiency and Economic Growth: the Case of India, European Journal of Economics, Finance and Administrative Sciences, 27, 130-138.

Nachmias F., Nachimias, D. (2009), Research Methods in the Social Science, United Kingdom: Hodder Educational Books ( $5^{\text {th }}$ Edition). 
Obamuyi, T. M. (2009), An Investigation of The Relationship Between Interest Rates and Economic Growth In Nigeria, 1970-2006, Journal of Economics and International Finance, 1(4), 93-98.

Obamuyi, T. M., Olorunfemi, S. (2011), Financial Reforms, Interest Rate Behaviour and Economic Growth In Nigeria, Journal of Applied Finance and Banking, 1(4), 39-55.

Odili, O., Ede, U. P. (2015), Evidence on the Dynamic Relationship Between Stock Market All Share Index and Gross Fixed Capital Formation in Nigeria, IOSR Journal of Business and Management, 17(1), 85-94.

Ogede, J. S. (2013), Interest Rate Sensitivity and Banks' Investment In Nigeria, Journal of Business Management and Applied Economics, 2(5), 1-9.

Ogege, S., Ezike, J. (2012), The Nigerian Capital Market and Economic Development: A Critical Appraisal, International Business Research, 5(8), 228-23.

Ogunbiyi, S. S., Ihejirika, P. O. (2014), Interest Rates and Deposit Money Banks’ Profitability Nexus: The Nigerian Experience, Arabian Journal of Business and Management Review (OMAN Chapter), 3(11), 133-148.

Ojima, D., Emerenini, F. (2015), Impact of Interest Rate on Investment in Nigeria, Developing Country Studies, 5(3), 103-109.

Onwumere, J. U. J., Okore, O. A., Ibe, I. G. (2012), The Impact of Interest Rate Liberalization on Savings and Investment: Evidence From Nigeria, Research Journal Of Finance and Accounting, 3(10), 130-136.

Osaze, B. E. (2000), The Nigerian capital Market in the African and Global Financial System, Benin City: Bofic Consulting Group Ltd.

Owolabi, A. U., Adegbite, T. A. (2014), Analysis of the Impacts of Interest Rate and Exchange Rate on Capital Market Performance in Nigeria, International Journal of Economics, Commerce and Management, 2(6), 1-11.

SEC (2009), Nigeria Capital Market: Making World-Class Potential a Reality, The Report of the SEC Committee on the Nigerian Capital Market, Abuja: NSEC, February.

Shaw, E. S. (1973), Financial Deepening In Economic Development, New York: Oxford University Press.

Siyanbola, T. T., Sobande, D., Adedeji, S. B. (2012), Effect of Interest Rate Deregulations on Banks Deposit Mobilization in Nigeria, International Journal Of Marketing and Technology, 2(9), 194-203.

Soyibo, A., Olayiwola, K. (2000), Interest Rate policy and The Promotion of Savings Investment and Resource Mobilisation in Nigeria, Development Policy Center Research Paper, 24, Ibadan: Development Policy Center.

Udoka, C. O., Anyingang, R. A. (2012), Effect of Interest Rate Fluctuation On The Economic Growth of Nigeria 1970-2010, International Journal of Business and Social Science, 3(20), 295-302. 